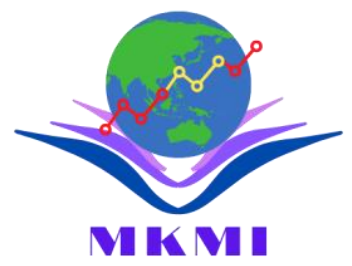

MEIIA KESEHATAN MASYARAKAT INDONESIA

p-ISSN: 1412-4920 e-ISSN: 2775-5614

https://ejournal.undip.ac.id/index.php/mkmi

Fakultas Kesehatan Masyarakat, Universitas Diponegoro

DOI :10.14710/mkmi.20.6.379-388

\title{
Faktor yang Berhubungan dengan Praktik PHBS Pencegahan TB Paru pada Santri di Kabupaten Tegal (Studi di Pondok Pesantren Attholibiyah Bumijawa)
}

\author{
Nissa Atul Asfiya ${ }^{1 *}$, Priyadi Nugraha Prabamurti ${ }^{1}$, Aditya Kusumawati ${ }^{1}$ \\ ${ }^{1}$ Bagian Promosi Kesehatan dan Ilmu Perilaku, Fakultas Kesehatan Masyarakat, Universitas Diponegoro \\ *Corresponding author : nissaasfiya@gmail.com
}

Info Artikel : Diterima 4 Agustus 2021 ; Disetujui 3 Oktober 2021; Publikasi 1 Desember 2021

\begin{abstract}
ABSTRAK
Latar Belakang : Perilaku Hidup Bersih dan Sehat merupakan pencegahan primer penularan TB Paru yang dapat dilakukan di pondok pesantren. Penelitian bertujuan untuk menganalisis faktor-faktor yang berhubungan dengan praktik PHBS pencegahan TB Paru pada santri di Kabupaten Tegal.

Metode : Penelitian kuantitatif dengan desain studi cross sectional. Populasi penelitian yaitu seluruh santri Pondok Pesantren Attholibiyah Bumijawa sebanyak 886 santri. Besar sampel sebanyak 268 santri, terdiri dari 130 santri putra dan 138 santri putri yang diperoleh dengan simple random sampling serta menggunakan perhitungan rumus Lemeshow. Pengumpulan data dengan pengisian kuesioner oleh responden. Analisis data dilakukan secara univariat, bivariat menggunakan uji chi-square dengan signifikansi 95\%, dan multivariat menggunakan uji regresi binary logistic. Penelitian ini sudah mendapat persetujuan dari komisi etik No : 90/EA/KEPK-FKM/2021.

Hasil : Hasil penelitian menunjukan 47\% responden memiliki perilaku PHBS pencegahan TB Paru dengan kategori kurang baik. Variabel yang berhubungan dengan praktik PHBS pencegahan TB Paru yaitu jenis kelamin $(p<0,01)$, tingkat pendidikan $(p=0,028)$, pengetahuan $(p=0,0002)$, sikap $(p<0,01)$, ketersediaan fasilitas $(p<0,01)$, ketersediaan informasi $(p<0,01)$, akses terhadap pelayanan kesehatan $(p<0,01)$, peraturan pondok $(p<0,01)$, sikap dan perilaku kyai $(p<0,01)$, sikap dan perilaku asatidz $(p<0,01)$, sikap dan perilaku pengurus $(p<0,01)$, serta sikap dan perilaku teman $(p<0,01)$. Variabel yang paling mempengaruhi praktik PHBS pencegahan TB Paru adalah jenis kelamin $(\mathrm{OR}=5,815)$.

Simpulan : Faktor yang berhubungan dengan praktik PHBS pencegahan TB Paru di pondok pesantren yaitu, jenis kelamin, tingkat pendidikan, pengetahuan, sikap, ketersediaan fasilitas, ketersediaan informasi, akses terhadap pelayanan kesehatan, peraturan pondok pesantren, sikap dan perilaku kyai, asatidz, serta pengurus dan teman. Sementara, faktor yang tidak berhubungan yaitu umur. Faktor yang paling berpengaruh yaitu jenis kelamin. Pondok pesantren sebagai institusi pendidikan perlu memberikan dukungan baik secara materi maupun sosial pada santri putra maupun putri, terutama pertimbangan pada santri putra dalam pelaksanaan PHBS pencegahan TB Paru di pondok pesantren.
\end{abstract}

Kata kunci : TB Paru, Perilaku Hidup Bersih Dan Sehat, Pondok Pesantren

\section{ABSTRACT}

Title : Factors Related to PHBS Practices for Preventing Pulmonary TB on Santri in Tegal Regency (Study at Pondok Pesantren Attholibyah Bumijawa) 
Background: PHBS is primary prevention of pulmonary TB transmission can be applied in Islamic boarding schools. This research to analyze the factors related to the practice of PHBS in preventing pulmonary TB among students in the Tegal Regency.

Method: Quantitative research with cross-sectional study design. The Population as many as 886 students, 268 samples are 130 male and 138 female students, obtained by simple random sampling using the Lemeshow formula. Collect data by filling out questionnaires by respondents. Analysis with univariate, bivariate using chi-square test, and multivariate using binary logistic regression test. This research has received approval from the ethics commission No: 90/EA/KEPK-FKM/2021.

Results: The results showed that $47 \%$ of respondents had PHBS behavior to prevent pulmonary TB in a poor category. The related variables were gender $(p<0,01)$, education level $(p=0.028)$, knowledge $(p=0.0002)$, attitude $(p<0,01)$, facilities $(p<0,01)$, information $(p<0,01)$, access to health services $(p<0,01)$, regulations $(p<0,01)$, kyai attitudes and behavior ( $p<0,01)$, asatidz ( $p<0,01)$, administrator $(p<0,01)$, friends $(p<0,01)$. The variable that most influenced the practice of $P H B S$ in preventing pulmonary $T B$ was gender $(O R=5.815)$.

Conclusion: Factors related to the practice of PHBS prevention of pulmonary TB in Islamic boarding schools are gender, education level, knowledge, attitudes, availability of facilities, availability of information, access to health services, boarding school regulations, attitudes, and behavior of kyai, asatidz, administrators and friends. The unrelated factor is age and the most influential factor is gender. Islamic boarding schools as educational institutions need to provide material and social support for male and female students, especially considerations for male students in the implementation of PHBS to prevent pulmonary TB in Islamic boarding schools.

Keywords: Pulmonary TB, Clean And Healthy Lifestyle, Islamic Boarding School.

\section{PENDAHULUAN}

Tuberkulosis (TB) merupakan penyakit menular yang disebabkan oleh bakteri Mycobacterium Tuberculosis. Penyakit ini menular melalui percikan droplet dari pasien TB BTA positif. TB menjadi salah satu dari sepuluh penyakit yang menjadi pembunuh infeksius teratas di dunia. ${ }^{1,2}$

Berdasarkan data dari WHO, Indonesia menjadi negara penyumbang kasus TB kedua di dunia sebesar $8,5 \%$, India menempati peringkat pertama sebesar $26 \%$, dan Cina di peringkat ketiga sebesar $8,4 \%{ }^{2}$ Berdasarkan data dari Kementerian Kesehatan Republik Indonesia kasus TB pada tahun 2017 sebanyak 420.994 kasus, tahun 2018 sebanyak 566.623 kasus dan pada tahun 2019 sebanyak 543.874 kasus. $45 \%$ kasus disumbangkan oleh provinsi dengan jumlah penduduk yang banyak yaitu Jawa Barat, Jawa Tengah, dan Jawa Timur. 3,4 Data dari Dinas Kesehatan Jawa Tengah angka notifikasi kasus TB di Jawa Tengah pada tahun 2017 sebesar 121 per 100.000 penduduk, tahun 2018 sebesar 134 per 100.000 penduduk, tahun 2019 sebesar 211 per 100.000 penduduk. ${ }^{5}$ Data dari Dinas Kesehatan Provinsi Jawa Tengah menunjukan angka notifikasi kasus TB di Kabupaten Tegal pada tahun 2017 sebesar 178, tahun 2018 menurun menjadi 161. Dan meningkat pada tahun 2019 menjadi 186. ${ }^{5,6,7}$ Berdasarkan data Profil Kesehatan Kabupaten Tegal, banyak jumlah kasus TB BTA+ terkonfirmasi di Kecamatan Bumijawa, pada tahun 2017 sebanyak 30 kasus, tahun 2018 sebanyak 36 kasus dan tahun 2019 sebanyak 52 kasus. ${ }^{8,9,10}$
Puskesmas Bumijawa menjadikan pondok pesantren sebagai tempat pelaksanaan program deteksi dini kelompok potensial penularan TB serta pelaksanaan program Poskestren (Pos Kesehatan Pesantren). Menurut Dinas Kesehatan Provinsi Jawa Tengah, kasus TB banyak teridentifikasi di lingkungan pondok pesantren. Hal ini terjadi karena kehidupan di pondok pesantren bersifat komunal serta kurang menjaga kebersihan dan kesehatan lingkungan. ${ }^{11}$ Penularan TB terjadi karena kehidupan santri yang sederhana dan apa adanya, terutama banyak ditemukan di pesantren dengan metode pendidikan salafi. ${ }^{12}$ Kebersihan lingkungan menjadi faktor penentu dalam penularan TB, kondisi atap, lantai, dan dinding yang jarang bahkan tidak dibersihkan menjadi tempat perkembangbiakan bakteri penyebab TB. Dan ketidakpedulian santri terhadap kebersihan lingkungan inilah yang menjadi faktor yang berisiko dalam penularan TB.

Perilaku Hidup Bersih dan Sehat (PHBS) menjadi upaya yang dapat dilakukan untuk mencegah penularan TB di pondok pesantren. Namun, dalam pelaksanaannya di pondok pesantren dikategorikan kurang baik, karena minimnya kesadaran santri. Keterbatasan pengetahuan dan wawasan yang menjadi faktor penyebab penularan TB di pondok pesantren. Pada dasarnya santri mengetahui mengenai PHBS, namun pengetahuan ini hanya sebatas pemahaman yang belum maksimal penerapannya. Sehingga, perlu adanya peningkatan kesadaran sebagai dasar dijadikannya praktik PHBS di pondok pesantren oleh santri. 
Tujuan penelitian ini untuk mengetahui dan menganalisis faktor-faktor yang berhubungan dengan praktik PHBS pencegahan TB paru pada santri Pondok Pesantren Attholibiyah Bumijawa Kabupaten Tegal, utamanya untuk mengetahui faktor yang memiliki pengaruh paling dominan terhadap praktik PHBS pencegahan TB Paru. Sehingga, dapat diketahui praktik PHBS yang dilaksanakan terhadap pencegahan penyakit TB Paru di lingkungan pondok pesantren.

\section{MATERI DAN METODE}

Penelitian ini merupakan penelitian kuantitatif. menggunakan rancangan studi cross sectional. Populasi penelitian adalah seluruh santri Pondok Pesantren Attholibiyah Bumijawa sebanyak 886 santri. Penentuan besar sampel menggunakan rumus Lemeshow dan didapatkan besar sampel sebanyak 268 santri, yaitu 130 santri putra dan 138 santri putri. Teknik pengambilan sampel menggunakan simple random sampling dengan cara undian dan nama yang keluar dipilih sebagai sampel penelitian. Pengambilan data menggunakan kuesioner terstruktur yang diisi oleh santri secara langsung di aula pondok pesantren di hari libur, peneliti mendampingi pengisian dan menjelaskan cara pengisian sebelum dibagikan.Variabel bebas pada penelitian ini adalah faktor pemudah (umur, jenis kelamin, tingkat pendidikan, pengetahuan, sikap), faktor pemungkin (ketersediaan fasilitas, ketersediaan informasi PHBS pencegahan TB Paru, akses terhadap pelayanan kesehatan, peraturan pondok pesantren), faktor penguat (sikap dan perilaku kyai, sikap dan perilaku asatidz, sikap dan perilaku pengurus, sikap dan perilaku teman). Variabel terikat pada penelitian ini yaitu praktik PHBS pencegahan TB Paru pada santri Pondok Pesantren Attholibiyah Bumijawa. Analisis data dilakukan secara univariat, bivariat, dan multivariat. Analisis univariat dilakukan untuk mengetahui persentase dan distribusi tiap variabel, analisis bivariat menggunakan uji chi-square dengan signifikansi $95 \%$ untuk mengetahui hubungan antar variabel, serta analisis multivariat menggunakan uji regresi binary logistic untuk mengetahui variabel yang paling dominan diantara variabel bebas terhadap variabel terikat.

\section{HASIL DAN PEMBAHASAN \\ Gambaran Umum Lokasi Penelitian}

Pondok Pesantren Attholibiyah berlokasi di Dukuh Mobok Karsih, Kelurahan Muncang Larang, Kecamatan Bumijawa Kabupaten Tegal Provinsi Jawa Tengah. Pondok pesantren didirikan pada tahun 2006. Saat ini, jumlah seluruh santri mencapai 886 santri, yaitu 430 santri putra dan 456 santri putri. Pondok pesantren termasuk pondok salafiyah dan terdapat pula sekolah umum dari jenjang SD, SMP, dan SMA yang dibangun di lingkungan pondok pesantren.

Tabel 1. Hasil Analisis Univariat

\begin{tabular}{|c|c|c|}
\hline Kategori & $\mathbf{F}$ & $\%$ \\
\hline \multicolumn{3}{|l|}{ Praktik } \\
\hline Baik & 142 & 53,0 \\
\hline Kurang baik & 126 & 47,0 \\
\hline \multicolumn{3}{|l|}{ Umur } \\
\hline Remaja awal (12-16 tahun) & 191 & 71,3 \\
\hline Remaja akhir (17-25 tahun) & 77 & 28,7 \\
\hline \multicolumn{3}{|l|}{ Jenis kelamin } \\
\hline Laki-laki & 130 & 48,5 \\
\hline Perempuan & 138 & 51,5 \\
\hline \multicolumn{3}{|l|}{ Tingkat pendidikan } \\
\hline Pendidkan rendah ( $\leq$ tamat SMP) & 229 & 85,4 \\
\hline Pendidikan tinggi (> tamat SMP) & 39 & 14,6 \\
\hline \multicolumn{3}{|l|}{ Pengetahuan } \\
\hline Baik & 140 & 52,2 \\
\hline Kurang baik & 128 & 47,8 \\
\hline \multicolumn{3}{|l|}{ Sikap } \\
\hline Mendukung & 165 & 61,6 \\
\hline Tidak mendukung & 103 & 38,4 \\
\hline \multicolumn{3}{|l|}{ Ketersediaan fasilitas } \\
\hline Lengkap & 162 & 60,4 \\
\hline Tidak lengkap & 106 & 39,6 \\
\hline \multicolumn{3}{|l|}{ Ketersediaan informasi } \\
\hline Memadai & 194 & 72,4 \\
\hline Tidak memadai & 74 & 27,6 \\
\hline \multirow{2}{*}{\multicolumn{3}{|c|}{ kesehatan }} \\
\hline & & \\
\hline Mudah & 137 & 51,1 \\
\hline Sulit & 131 & 48,9 \\
\hline \multicolumn{3}{|l|}{ Peraturan pondok pesantren } \\
\hline Ada & 174 & 64,9 \\
\hline Tidak ada & 94 & 35,1 \\
\hline \multicolumn{3}{|l|}{ Sikap dan perilaku kyai } \\
\hline Mendukung & 181 & 67,5 \\
\hline Tidak mendukung & 87 & 32,5 \\
\hline \multicolumn{3}{|l|}{ Sikap dan perilaku asatidz } \\
\hline Mendukung & 162 & 60,4 \\
\hline Tidak mendukung & 106 & 39,6 \\
\hline \multicolumn{3}{|l|}{ Sikap dan perilaku pengurus } \\
\hline Mendukung & 223 & 83,2 \\
\hline Tidak mendukung & 45 & 16,8 \\
\hline \multicolumn{3}{|l|}{ Sikap dan perilaku teman } \\
\hline Mendukung & 182 & 67,9 \\
\hline Tidak mendukung & 86 & 32,1 \\
\hline
\end{tabular}

Sumber : Data Primer 2021

Berdasarkan tabel 1 diketahui bahwa karakteristik responden dalam penelitian ini mayoritas dalam kategori remaja awal (71,3\%), berjenis kelamin perempuan $(51,5 \%)$, dan memiliki tingkat pendidikan 
rendah $(85,4 \%)$. Adapun pembahasan variabel lain yaitu sebagai berikut :

1. Pengetahuan

Sebesar $47,8 \%$ responden berpengetahuan kurang baik, dengan rincian responden mengetahui bahwa TB Paru merupakan penyakit menular $(86,2 \%)$, responden menjawab benar bahwa penyebab TB adalah Mycobacterium Tuberculosis $(88,1 \%)$, serta responden menjawab bahwa gejala TB Paru yaitu batuk selama lebih dari 2 minggu $(70,5 \%)$.

Responden tidak mengetahui bahwa perilaku yang dapat menularkan TB antara lain : membuang dahak sembarangan $(65,3 \%)$, tidak membuka jendela dari pagi hingga sore hari $(68,7 \%)$, menggunakan alat mandi bersama $(69,4 \%)$, makan bersama dalam satu wadah $(56,0 \%)$, tidak mencuci tangan setelah makan $(58,2 \%)$. Responden tidak mengetahui faktor penyebab TB, seperti kepadatan hunian kamar (54,9\%), pencahayaan $(86,6 \%)$, ventilasi $(70,9 \%)$, kondisi lantai $(63,1 \%)$, dan perilaku $(71,3 \%)$. Responden tidak mengetahui bahwa pengasuh, asatidz, pengurus dapat menularkan TB Paru. Namun, responden mengetahui bahwa teman $(94,8 \%)$ dapat menularkan TB Paru.

2. Sikap

Sebesar $(38,4 \%)$ responden tidak mendukung pelaksanaan PHBS untuk mencegah TB Paru di pondok pesantren, $(29,5 \%)$ responden akan menerapkan PHBS setelah terinfeksi TB Paru, namun responden menjaga kebersihan badan secara teratur setiap hari $(98,9 \%)$, menjaga kebersihan pakaian secara teratur $(98,5 \%)$, rutin olahraga $(98,1 \%)$, menggunakan air bersih untuk mandi $(98,1 \%)$, menjaga kebersihan lingkungan (98,9\%), memperhatikan asupan gizi (94,4\%), membuka jendela pada pagi hingga sore hari $(92,2 \%)$, tidak meminjamkan pakaian kepada teman $(63,1 \%)$.

3. Ketersediaan fasilitas

Ketersediaan fasilitas (39,6\%) tidak lengkap, hal ini karena ketersediaan ventilasi belum ada di setiap kamar, belum ada wastafel dan sabun untuk cuci tangan di setiap komplek. Namun, ketersediaan fasilitas lain dalam kategori lengkap seperti: ketersediaan alas tidur $(97,0 \%)$, air bersih $(96,6 \%)$, sapu $(94,4 \%)$, tempat sampah $(98,5 \%)$, jendela $(96,6 \%)$, kamar perawatan $(97,4 \%)$, poskestren $(98,1 \%)$, obat-obatan/P3K $(97,8 \%)$.

4. Ketersediaan informasi

Ketersediaan informasi di pondok pesantren $(27,6 \%)$ tidak memadai, karena tidak tersedia banner dan poster dari puskesmas maupun pondok pesantren. Akan tetapi ketersediaan informasi lain dalam kategori memadai, seperti : penyuluhan dari poskestren mengenai PHBS $(92,5 \%)$, penyuluhan dari tenaga kesehatan $(92,9 \%)$.

5. Akses terhadap pelayanan kesehatan

$(48,9 \%)$ responden menyatakan bahwa sulit mengakses pelayanan kesehatan, responden masih merasa jarak yang ditempuh ke pelayanan kesehatan di luar pondok pesantren tergolong jauh, sehingga waktu yang ditempuh ke pelayanan kesehatan lama, namun responden menyatakan biaya pengobatan terjangkau $(86,9 \%)$, sarana transportasi mudah ditemukan $(86,6 \%)$, serta biaya transportasi terjangkau $(84,0 \%)$.

6. Peraturan pondok pesantren

$(35,1 \%)$ responden menyatakan bahwa tidak ada peraturan di pondok pesantren, salah satu peraturan yang tidak ada yaitu cek kesehatan berkala yang dilakukan oleh pondok pesantren untuk santri. Namun, peraturan lain mengenai PHBS pencegahan TB Paru ada di pondok pesantren, seperti pernyataan responden mengenai ro'an sebagai salah satu pelaksanaan PHBS di pondok pesantren $(87,7 \%)$, aturan menjaga kebersihan kamar $(95,5 \%)$, sanksi kepada santri yang tidak melakukan PHBS $(88,1 \%)$.

7. Sikap dan perilaku kyai

$(32,5 \%)$ responden menyatakan sikap dan perilaku kyai dalam kategori tidak mendukung seperti kyai tidak melakukan pengecekan pelaksanaan PHBS secara langsung dan tidak memberikan sanksi kepada santri yang tidak menerapkan PHBS di pondok. Namun, responden menjawab bahwa kyai mengingatkan (98,9\%), menegur $(90,3 \%)$, mengecek $(82,5 \%)$, memberi contoh $(95,9 \%)$ dalam pelaksanaan PHBS di pondok pesantren.

8. Sikap dan perilaku asatidz

$(39,6 \%)$ responden menyatakan bahwa sikap dan perilaku asatidz tidak mendukung PHBS pencegahan TB Paru, asatidz tidak melakukan pengecekan secara langsung terhadap pelaksanaan PHBS, tidak memberikan sanksi kepada santri yang tidak menjaga kebersihan. Namun, asatidz mengingatkan $(88,1 \%)$, memberi contoh PHBS kepada santri $(89,6 \%)$.

9. Sikap dan perilaku pengurus

$(16,8 \%)$ responden menyatakan bahwa pengurus tidak mendukung PHBS pencegahan TB Paru. Namun, responden menyatakan bahwa pengurus memberi sanksi $(90,7 \%)$, mengingatkan $(96,6 \%)$, menegur $(92,5 \%)$, melakukan pengecekan (90,3\%), memberi contoh (92,9\%) PHBS pencegahan TB Paru.

10. Sikap dan perilaku teman

$(32,1 \%)$ responden menyatakan bahwa sikap dan perilaku teman tidak mendukung PHBS pencegahan TB Paru, masih ada teman yang belum 
membantu dalam memahami informasi PHBS pencegahan TB sebesar (67,9\%). Namun, responden menyatakan bahwa teman memberikan informasi (82,5\%), mengingatkan (89,9\%), menegur $(84,7 \%)$, membiasakan diri berperilaku hidup bersih dan sehat $(91,0 \%)$.

Tabel 2. Hasil Analisis Bivariat Variabel Bebas dengan Praktik PHBS Pondok Pesantren Attholibiyah Bumijawa

\begin{tabular}{|c|c|c|c|c|c|c|c|c|}
\hline \multirow{3}{*}{ Variabel } & \multicolumn{6}{|c|}{ Praktik PHBS } & \multirow{3}{*}{ P-Value } & \multirow{3}{*}{$\begin{array}{l}\text { Odds } \\
\text { ratio }\end{array}$} \\
\hline & \multicolumn{2}{|c|}{ Kurang baik } & \multicolumn{2}{|c|}{ Baik } & \multicolumn{2}{|c|}{ Total } & & \\
\hline & $\mathbf{F}$ & $\%$ & $\mathbf{F}$ & $\%$ & $\mathbf{F}$ & $\%$ & & \\
\hline \multicolumn{9}{|l|}{ Umur } \\
\hline Remaja awal (12-16 tahun) & 97 & 51,0 & 94 & 49,0 & 191 & 71,3 & 0,051 & - \\
\hline Remaja akhir (17-25 tahun) & 29 & 38,0 & 48 & 62,0 & 77 & 28,7 & & \\
\hline \multicolumn{9}{|l|}{ Jenis kelamin } \\
\hline Laki - laki & 104 & 80,0 & 26 & 20,0 & 130 & 48,5 & 0,000 & 5.815 \\
\hline Perempuan & 22 & 16,0 & 116 & 84,0 & 138 & 51,5 & & \\
\hline \multicolumn{9}{|l|}{ Tingkat pendidikan } \\
\hline Pendidkan rendah ( $\leq$ tamat SMP) & 114 & 49,8 & 115 & 50,2 & 229 & 85,4 & 0,028 & \\
\hline Pendidikan tinggi (> tamat SMP) & 12 & 30,8 & 27 & 69,2 & 39 & 14,6 & & 2.458 \\
\hline \multicolumn{9}{|l|}{ Pengetahuan } \\
\hline Kurang baik & 73 & 57,0 & 55 & 43,0 & 128 & 52,2 & 0,002 & 1.829 \\
\hline Baik & 53 & 38,0 & 87 & 62,0 & 140 & 47,8 & & \\
\hline \multicolumn{9}{|l|}{ Sikap } \\
\hline Mendukung & 48 & 29,0 & 117 & 71,0 & 165 & 61,6 & 0,000 & 2.275 \\
\hline Tidak mendukung & 78 & 75,7 & 25 & 24,3 & 103 & 38,4 & & \\
\hline \multicolumn{9}{|l|}{ Ketersediaan fasilitas } \\
\hline Lengkap & 49 & 30,0 & 113 & 70,0 & 162 & 60,4 & 0,000 & 1.985 \\
\hline Tidak lengkap & 77 & 73,0 & 29 & 27,0 & 106 & 39,6 & & \\
\hline \multicolumn{9}{|l|}{ Ketersediaan informasi } \\
\hline Memadai & 63 & 32,5 & 131 & 67,5 & 194 & 72,4 & 0,000 & 2.726 \\
\hline Tidak memadai & 63 & 85,0 & 11 & 15,0 & 74 & 27,6 & & \\
\hline Akses terhadap & & & & & & & & \\
\hline kesehatan & & & & & & & & 1.365 \\
\hline Mudah & 45 & 33,0 & 92 & 67,0 & 137 & 51,1 & 0,000 & \\
\hline Sulit & 81 & 61,8 & 50 & 38,0 & 131 & 48,9 & & \\
\hline \multicolumn{9}{|l|}{ Peraturan pondok pesantren } \\
\hline Ada & 53 & 30,0 & 121 & 70,0 & 174 & 64,9 & & 2.818 \\
\hline Tidak ada & 71 & 77,2 & 21 & 22,8 & 92 & 35,1 & 0,000 & \\
\hline \multicolumn{9}{|l|}{ Sikap dan perilaku kyai } \\
\hline Mendukung & 59 & 32,6 & 122 & 67,4 & 181 & 67,5 & 0,000 & .884 \\
\hline Tidak mendukung & 67 & 77,0 & 20 & 23,0 & 87 & 32,5 & & \\
\hline \multicolumn{9}{|l|}{ Sikap dan perilaku asatidz } \\
\hline Mendukung & 40 & 24,7 & 122 & 75,3 & 162 & 60,4 & 0,000 & 1.486 \\
\hline Tidak mendukung & 86 & 81,0 & 20 & 19,0 & 106 & 39,6 & & \\
\hline \multicolumn{9}{|l|}{ Sikap dan perilaku pengurus } \\
\hline Mendukung & 86 & 38,6 & 137 & 61,4 & 223 & 83,2 & 0,000 & 1.372 \\
\hline Tidak mendukung & 40 & 89,0 & 5 & 11,0 & 45 & 16,8 & & \\
\hline \multicolumn{9}{|l|}{ Sikap dan perilaku teman } \\
\hline Mendukung & 55 & 30,2 & 127 & 69,8 & 182 & 67,9 & 0,000 & 1.708 \\
\hline Tidak mendukung & 71 & 82,6 & 15 & 17,4 & 86 & 32,1 & & \\
\hline
\end{tabular}

Sumber : Data primer 2021 


\section{Hubungan umur dengan praktik PHBS pencegahan TB Paru}

Hasil penelitian menunjukan remaja awal (12-16 tahun) memiliki presentase praktik PHBS pencegahan TB Paru kurang baik lebih besar yaitu $51 \%$ dibandingkan dengan remaja akhir (17-25 tahun) sebesar $38 \%$. Hasil pengujian hipotesis menunjukan $p$-value 0,051>0,05 dapat disimpulkan bahwa tidak ada hubungan antara umur dengan praktik PHBS pencegahan TB Paru.

Penelitian ini sejalan dengan penelitian Lili yang menunjukan bahwa tidak ada hubungan yang bermakna antara umur dengan PHBS pada mahasiswa kos $(p=0,5440){ }^{13}$

Teori L. Green menjelaskan bahwa umur merupakan faktor pemudah yang membentuk perilaku. Berdasarkan penelitian tidak ada perbedaan antara umur remaja awal maupun akhir, hal ini karena peraturan pondok pesantren tidak memberikan toleran kepada umur tertentu, semua peraturan berlaku untuk seluruh santri, sehingga seluruh santri mendapat perlakuan yang sama dalam pelaksanaan kegiatan di pondok pesantren.

\section{Hubungan jenis kelamin dengan praktik PHBS pencegahan TB Paru}

Hasil penelitian menunjukan laki-laki memiliki presentase praktik PHBS pencegahan TB Paru kurang baik lebih besar yaitu $80,0 \%$ dibandingkan dengan perempuan. Hasil pengujian hipotesis menunjukan $p$-value $<0,01$ dapat disimpulkan bahwa ada hubungan antara jenis kelamin dengan praktik PHBS pencegahan TB Paru pada santri.

Hasil penelitian Zulfa mengenai perbedaan pengetahuan dan sikap perilaku hidup bersih dan sehat (PHBS) antara santri putra dan santri putri yang menunjukkan bahwa kelompok putri lebih baik daripada pada kelompok putra dalam pelaksanaan PHBS di pondok pesantren. ${ }^{14}$

Teori L.Green menyebutkan bahwa jenis kelamin merupakan faktor pemudah yang membentuk perilaku. Jenis kelamin memberi pengaruh dalam praktik PHBS pencegahan TB Paru. Dalam praktiknya laki-laki kurang peduli terhadap PHBS pencegahan TB Paru, karena terdapat praktik merokok terutama pada santri laki-laki, kemudian banyak dari santri laki-laki yang tidak menjaga kebersihan kamar, bersikap seadanya dan kurang peduli terhadap kebersihan kamar.

\section{Hubungan tingkat pendidikan dengan praktik PHBS pencegahan TB Paru}

Hasil penelitian menunjukan responden dengan kategori pendidikan rendah $(\leq \mathrm{SMP})$ memiliki presentase praktik PHBS pencegahan TB Paru kurang baik lebih besar yaitu 49,8\%. Hasil pengujian hipotesis menunjukan $p$ - value $0,028<0,05$ dapat disimpulkan bahwa ada hubungan antara tingkat pendidikan dengan praktik PHBS pencegahan TB Paru pada santri.
Hasil penelitian ini sejalan dengan penelitian Zaraz menunjukan adanya hubungan antara tingkat pendidikan dengan praktik PHBS. Jenjang pendidikan memiliki peranan penting dalam kesehatan masyarakat. Pendidikan masyarakat yang rendah menjadikan responden sulit diberitahu mengenai pentingnya hygiene perorangan dan sanitasi lingkungan. ${ }^{15}$

Berdasarkan teori L. Green tingkat pendidikan merupakan faktor pemudah yang membentuk perilaku. Pendidikan merupakan salah satu usaha dalam pengorganisasian masyarakat untuk meningkatkan pengetahuan termasuk pengetahuan kesehatan. Semakin baik tingkat pendidikan akan mematangkan pemahaman tentang pengetahuan kesehatan termasuk penerapan prinsip-prinsip PHBS. Dalam kurikulum pendidikan terdapat materi yang menjelaskan tentang pentingnya menjaga kesehatan, seperti tidak membuang sampah sembarangan, melaksanakan pemberantasan jentik nyamuk dan lain sebagainya. Sehingga semakin tinggi tingkat pendidikan lebih banyak pemahaman yang didapatkan di jenjang pendidikan yang ditempuh, maka akan semakin baik praktik PHBS pencegahan TB Paru yang dilaksanakan.

\section{Hubungan pengetahuan dengan praktik PHBS pencegahan TB Paru}

Hasil penelitian responden dengan kategori pengetahuan kurang baik memiliki presentase praktik PHBS pencegahan TB Paru kurang baik lebih besar yaitu $57,0 \%$. Hasil pengujian hipotesis menunjukan $p$-value $0,002<0,05$ dapat disimpulkan bahwa ada hubungan antara pengetahuan dengan praktik PHBS pencegahan TB Paru pada santri.

Hasil penelitian Abdul menunjukan ada hubungan antara pengetahuan dengan sikap positif terhadap praktik PHBS. ${ }^{16}$ Berdasarkan teori L.Green pengetahuan merupakan faktor pemudah, karena pengetahuan menjadi pemicu, dasar atau motivasi bertindak. Pengetahuan memiliki keterkaitan dengan perilaku, hal ini dikarenakan individu dengan pengetahuan yang baik mampu membedakan mana baik dan buruk untuk dirinya maupun lingkungan, sehingga individu dengan pengetahuan yang baik akan bertindak atas apa yang mereka ketahui dan pahami, terutama dalam pelaksanaan PHBS pencegahan TB Paru.

\section{Hubungan sikap dengan praktik PHBS pencegahan TB Paru}

Hasil penelitian responden dengan kategori sikap tidak mendukung memiliki presentase praktik PHBS pencegahan TB Paru kurang baik lebih besar yaitu $75,7 \%$. Hasil pengujian hipotesis menunjukan $p-$ value $<0,01$ dapat disimpulkan bahwa ada hubungan antara sikap responden dengan praktik PHBS pencegahan TB Paru pada santri.

Penelitian ini sejalan dengan penelitian Fanny yang menunjukan ada hubungan antara sikap dan 
praktik PHBS pencegahan TB Paru di pondok pesantren, responden dengan sikap mendukung dominan melakukan PHBS pencegahan TB Paru lebih baik. ${ }^{17}$

Hal ini sesuai dengan teori $L$. Green bahwa sikap merupakan faktor pemudah yang mempengaruhi individu dalam berperilaku. Sikap mendasari sebuah perilaku, dengan sikap yang positif adopsi perilaku akan bersifat langgeng, sikap belum suatu tindakan, akan tetapi suatu kesiapan untuk bertindak dan menjadi predisposi dalam suatu tindakan. Sikap merupakan turunan dari pengetahuan, sikap yang baik ditunjukan dengan menerima, merespon, menghargai dan bertanggung jawab terhadap perilaku individu dan praktik PHBS pencegahan TB Paru. Penanaman moral kepada santri bahwa kebersihan merupakan sebagian dari iman mendukung untuk melaksanakan PHBS pencegahan TB Paru yang lebih baik.

\section{Hubungan ketersediaan fasilitas dengan praktik PHBS pencegahan TB Paru}

Hasil penelitian praktik PHBS pencegahan TB Paru yang kurang baik terjadi jika ketersediaan fasilitas tidak lengkap $(73,0 \%)$ dibandingkan dengan ketersediaan fasilitas lengkap (30,0\%). Hasil pengujian hipotesis menunjukan $p$-value $<0$, dapat disimpulkan bahwa ada hubungan antara ketersediaan fasilitas dengan praktik PHBS pencegahan TB paru pada santri.

Hasil penelitian Linda menunjukan adanya pengaruh antara fasilitas dengan praktik PHBS. Jika ketersediaan fasilitas memenuhi syarat maka akan mendorong individu untuk menerapkan PHBS. ${ }^{18}$

Hal ini sesuai dengan teori L.Green bahwa ketersediaan fasilitas merupakan faktor pemungkin dalam mempengaruhi perilaku individu. Faktor ini mendukung atau memungkinkan terwujudnya perilaku kesehatan individu. Ketersediaan fasilitas seperti adanya tempat sampah, tempat untuk cuci tangan dan sabun, ketersediaan kamar mandi akan memberikan dampak yang baik terhadap perilaku dibandingkan dengan tidak adanya fasilitas, karena adanya fasilitas dapat memberikan dorongan individu untuk berperilaku sehat.

\section{Hubungan ketersediaan Informasi dengan praktik PHBS pencegahan TB Paru}

Hasil penelitian menunjukan praktik PHBS responden kurang baik ditemukan jika ketersediaan informasi tidak memadai yaitu sebesar $85,0 \%$. Hasil pengujian hipotesis menunjukan $p$-value $<0,01$ dapat disimpulkan bahwa ada hubungan antara ketersediaan informasi dengan praktik PHBS pencegahan TB Paru pada santri.

Hasil penelitian ini sejalan dengan penelitian Murniani yang menunjukan adanya hubungan yang bermakna antara sumber informasi dengan praktik PHBS pada tatanan rumah tangga di wilayah kerja Puskesmas Melintang. ${ }^{19}$
Berdasarkan teori L.Green ketersediaan informasi menjadi faktor pemungkin dalam suatu tindakan atau perilaku kesehatan individu. Ketersediaan informasi dapat mempengaruhi dan meningkatkan pengetahuan pada individu. Banyak informasi kesehatan yang ditayangkan melalui media yang dapat memberikan gambaran bagaimana PHBS harus dilaksanakan.

\section{Hubungan akses Terhadap Pelayanan Kesehatan dengan praktik PHBS pencegahan TB Paru}

Hasil penelitian menunjukan praktik PHBS responden kurang baik ditemukan jika akses terhadap pelayanan kesehatan dalam kategori sulit $(61,8 \%)$. Hasil pengujian hipotesis menunjukan $p$ value $<0,01$ dapat disimpulkan bahwa ada hubungan antara akses terhadap pelayanan kesehatan dengan praktik PHBS pencegahan TB Paru pada santri.

Hasil penelitian sejalan dengan Kusumaningrum bahwa ada hubungan yang signifikan antara jarak pelayanan kesehatan terhadap pemanfaatan pelayanan kesehatan $(p$-value $<0,01) .{ }^{20}$ Aksesibilitas merupakan keterjangkauan terhadap fasilitas kesehatan. Pertimbangan jarak dan biaya mempengaruhi seseorang untuk melakukan PHBS.

Hal ini sejalan dengan teori L.Green yang menjelaskan bahwa akses terhadap pelayanan kesehatan menjadi faktor pemungkin yang mempengaruhi perilaku individu. Fasilitas yang mudah dijangkau maka fasilitas tersebut akan banyak dimanfaatkan oleh masyarakat. Selain itu, keterjangkauan akses mempengaruhi dalam pembiayaan, semakin mudah akses fasilitas kesehatan maka pembiayaan semakin murah dan mendorong individu untuk datang ke fasilitas kesehatan.

\section{Hubungan peraturan pondok pesantren dengan praktik PHBS pencegahan TB Paru}

Hasil penelitian diketahui praktik PHBS kurang baik ditemukan jika tidak ada peraturan di pondok pesantren sebesar 77,2\%. Hasil pengujian hipotesis menunjukan $p$-value $<0,01$ dapat disimpulkan bahwa ada hubungan antara peraturan pondok dengan praktik PHBS pencegahan TB Paru pada santri.

Hasil penelitian ini sejalan dengan penelitian Fanny yang menunjukan ada hubungan antara peraturan pondok dengan praktik PHBS pencegahan TB Paru di pondok pesantren dengan $p$-value 0,007 $<0,05 .{ }^{17}$

Hal ini sejalan dengan teori L.Green bahwa peraturan merupakan faktor pemungkin seseorang dalam berperilaku. Melalui peraturan seseorang dapat menanamkan akhlak dan budi pekerti yang baik serta membentuk kebiasaan-kebiasaan yang baik. Peraturan memaksa individu untuk berperilaku, sehingga memberikan pengaruh terhadap perilaku yang dilakukan oleh individu. Di pondok pesantren mendapat sanksi ta'ziran merupakan hal yang memalukan, karena tidak mematuhi peraturan, maka 
semakin ketat dan baik peraturan pondok, maka semakin baik perilaku santri di pondok pesantren.

\section{Hubungan sikap dan perilaku kyai dengan praktik PHBS pencegahan TB Paru}

Hasil penelitian menunjukan responden dengan praktik PHBS kurang baik ditemukan jika tidak mendapat dukungan dari kyai $(77,0 \%)$. Hasil pengujian hipotesis menunjukan $p$-value $<0,01$ dapat disimpulkan bahwa ada hubungan antara sikap dan perilaku kyai dengan praktik PHBS pencegahan TB Paru pada santri.

Hal ini sejalan dengan penelitian Fanny yang menunjukan ada hubungan antara dukungan kyai dengan praktik PHBS. ${ }^{17}$ Kepemimpinan kyai yang memegang teguh nilai luhur, menjadikan kyai sebagai tauladan serta dihormati oleh santrinya. Santri selalu taat dan patuh terhadap perintah kyai, sehingga setiap perintah yang diberikan kyai akan dilaksanakan oleh santri. Maka, kepemimpinan kyai menjadi pengaruh terhadap perilaku yang diterapkan oleh santri-santri di pondok pesantren.

Berdasarkan teori L.Green sikap dan perilaku kyai merupakan faktor penguat dalam mempengaruhi perilaku. Kyai sebagai guru dan pengambil keputusan di pondok pesantren menjadi komponen utama yang mengontrol, menghimbau dan mempengaruhi dalam pembentukan sikap yang dapat mempengaruhi perilaku kesehatan santri di pondok pesantren.

\section{Hubungan sikap dan perilaku asatidz dengan praktik PHBS pencegahan TB Paru}

Hasil penelitian menunjukan praktik PHBS responden kurang baik jika tidak mendapat dukungan dari asatidz (81,0\%). Hasil pengujian hipotesis menunjukan p-value $<0,01$ dapat disimpulkan bahwa ada hubungan antara sikap dan perilaku asatidz dengan praktik PHBS pencegahan TB Paru pada santri.

Penelitian ini sejalan dengan penelitian Martinus bahwa ada pengaruh signifikan $(p=0,001)$ antara keteladanan guru sebagai role model terhadap motivasi siswa dalam menerapkan PHBS di SMP Frater Parepare. ${ }^{21}$ Maka jika keteladanan guru bertambah makan akan semakin baik pula siswa dalam meniru guru.

Hal ini sejalan dengan teori L.Green bahwa ada 3 faktor yang mempengaruhi perilaku, salah satunya adalah faktor penguat yaitu sikap dan perilaku guru. Guru atau di pondok pesantren dipanggil asatidz/ustadz merupakan komponen sosial yang dapat mempengaruhi sikap yang mendorong santri untuk berperilaku. Perannya sebagai pengajar dapat memberikan dukungan dengan memberikan pengetahuan, informasi mengenai pentingnya menjaga kebersihan diri dan lingkungan pondok pesantren.

\section{Hubungan sikap dan perilaku pengurus dengan praktik PHBS pencegahan TB Paru}

Hasil penelitian menunjukan praktik PHBS kurang baik ditemukan jika tidak mendapat dukungan dari pengurus pondok pesantren sebesar $89,0 \%$. Hasil pengujian hipotesis menunjukan $p$ value $<0,01$ dapat disimpulkan bahwa ada hubungan antara sikap dan perilaku pengurus pondok pesantren dengan praktik PHBS pencegahan TB Paru pada santri.

Hasil penelitian sejalan dengan penelitian Fanny yang menunjukan adanya hubungan antara dukungan pengurus dengan praktik PHBS pencegahan penyakit TB Paru. ${ }^{17}$ Pengurus merupakan penegak peraturan, sehingga peranannya memberikan pengaruh terhadap perilaku santri.

Hal ini sesuai dengan teori L.Green yang menjelaskan bahwa faktor penguat yakni sikap dan perilaku dari pengurus pondok pesantren menjadi salah satu faktor yang mempengaruhi perilaku individu. Pengurus pondok sebagai penegak peraturan yang memberikan kebijakan serta sanksi bagi santri menjadi salah satu faktor yang dapat mendorong santri untuk berperilaku sehat. Perannya sebagai pengontrol dapat menjadi pengingat, penghimbau dan penggerak santri dalam melaksanakan PHBS di pondok pesantren.

\section{Hubungan sikap dan perilaku teman dengan praktik PHBS pencegahan TB Paru}

Hasil penelitian menunjukan praktik PHBS responden kurang baik ditemukan jika tidak mendapat dukungan dari teman $(82,6 \%)$. Hasil pengujian hipotesis menunjukan $p$-value $<0,01$ dapat disimpulkan bahwa ada hubungan antara sikap dan perilaku teman dengan praktik PHBS pencegahan TB Paru pada santri.

Hasil penelitian ini sejalan dengan penelitian Novi yang menunjukan ada pengaruh yang signifikan terhadap praktik PHBS dengan pengaruh teman sebaya dengan p-value $0,000 .{ }^{22}$ Teman dengan perilaku hidup bersih dan sehat yang baik akan memberikan dampak positif dibandingkan dengan teman dengan perilaku hidup bersih dan sehat yang kurang baik.

Hal ini sejalan dengan teori L.Green dimana perilaku dipengaruhi oleh 3 faktor salah satunya adalah faktor penguat. Teman merupakan komponen sosial yang memiliki pengaruh dalam pembentukan perilaku. Kegiatan santri yang banyak dilakukan bersama menjadikan teman sebagai faktor penguat dalam pembentukan sikap yang mendorong perilaku, sehingga berpengaruh dalam pelaksanaan PHBS pencegahan TB Paru di pondok pesantren.

\section{SIMPULAN}

Penelitian kepada 268 santri, yaitu 130 santri putra dan 138 santri putri menunjukan bahwa praktik PHBS pencegahan TB Paru pada santri Pondok 
Pesantren Attholibiyah dalam kategori baik sebesar $53,0 \%$. Mayoritas responden dalam kategori remaja awal (12-16 tahun), berjenis kelamin perempuan dan berpendidikan rendah, serta memiliki pengetahuan baik, sikap mendukung, ketersediaan fasilitas lengkap, informasi memadai, akses mudah, adanya peraturan pondok, dukungan dari kyai, asatidz, pengurus dan teman dalam pelaksanaan PHBS pencegahan TB Paru di pondok pesantren.

Variabel yang berhubungan dengan praktik PHBS pencegahan TB Paru yaitu pengetahuan ( $p=$ $0,0002)$, tingkat pendidikan $(p=0,028)$, dan variabel dengan $p$-value $<0,01$ (jenis kelamin, sikap, ketersediaan fasilitas, ketersediaan informasi, akses terhadap pelayanan kesehatan, peraturan pondok , sikap dan perilaku kyai, sikap dan perilaku asatidz, sikap dan perilaku pengurus, sikap dan perilaku teman). Variabel yang tidak ada hubungan yaitu, umur $(p=0,051)$. Variabel yang paling mempengaruhi praktik PHBS pencegahan TB Paru yaitu jenis kelamin $(p=0,0001)$ dengan nilai $\mathrm{OR}=$ 5,815 .

\section{DAFTAR PUSTAKA}

1. Groenewald W, Baird MS, Verschoor JA, Minnikin DE, Croft AK. Differential spontaneous folding of mycolic acids from Mycobacterium tuberculosis. Chem Phys Lipids. 2014;180:15-22.

2. World Health Organization. Global Tuberculosis Report 2020. geneva; 2020.

3. World Health organization. Global Tuberculosis Report 2019. geneva; 2019.

4. Kementerian Kesehatan Indonesia 2019. Profil Kementerian Kesehatan Indonesia 2019. Vol. 53, Kementerian Kesehatan RI. 2019. 1689 1699 p.

5. Badan Pusat Statistik Provinsi Jawa tengah. Profil Kesehatan Provinsi Jawa Tengah 2019. Sosial BS, editor. Semarang; 2019.

6. Dinas Kesehatan Provinsi Jawa Tengah. Profil Kesehatan Jawa tengah Tahun 2017 [Internet]. Semarang; 2019 [cited 2020 Oct 26]. Available from:

http://dinkesjatengprov.go.id/v2018/dokumen/ Profil2017/mobile/index.html\#p=88

7. Dinas Kesehatan Provinsi Jawa Tengah. Profil Kesehatan Provinsi Jateng 2018 [Internet]. 2019 [cited 2020 Oct 26]. Available from: http://dinkesjatengprov.go.id/v2018/dokumen/p rofil_2018/mobile/index.html

8. Dinkes Kabupaten Tegal. Profil Kesehatan Kabupaten Tegal Tahun 2018. 2019.

9. Dinas Kesehatan Kabupaten Tegal. Profil Kesehatan KabupatenTegal 2019. 2019.

10. Dinkes Tegal. Profil Kesehatan Kabupaten Tegal Tahun 2017. 2018;225.

11. Zulfa M, Alawi A. Gus Yus: Fisik Santri Lemah, Unggul Jiwa [Internet]. 2015 [cited
2020 Nov 22]. Available from: https://www.nu.or.id/post/read/58288/gus-yusfisik-santri-lemah-unggul-jiwa

12. Fauzi, Dkk. Peran Pendidikan Pesantren Salafi Dalam Membentuk Perilaku Remaja Di Era Modernisasi. J Ika Ikat Alumni Pgsd Unars. 2020;8(1):179-87.

13. Ariani L. Faktor-faktor yang mempengaruhi perilaku hidup bersih dan sehat pada mahasiswa kos di Padukuhan Karangmalang Yogyakarta. Jurkessia. 1390;VIII(1):99-117.

14. Zulfa Husni Khumayra MS. Perbedaan Pengetahuan dan Sikap Perilaku Hidup Bersih dan Sehat (PHBS) antara Santri Putra dan Santri Putri. J Nutr Coll. 2012;3(1):90-7.

15. Adliyani ZON, Angraini DI, Soleha TU. Pengaruh Pengetahuan, Pendidikan dan Ekonomi terhadap Perilaku Hidup Bersih dan Sehat pada Masyarakat Desa Pekonmon Kecamatan Ngambur Kabupaten Pesisir Barat. Major J. 2017;7(1):6-13.

16. Lewa AF, Ramadhan K. Pengetahuan dan Sikap Santri tentang PHBS dengan Tindakan Penerapan PHBS di Pondok Pesantren Amanah Putra Poso. Poltekita J Ilmu Kesehat [Internet]. 2015;1(19):986-91. Available from: http://garuda.ristekbrin.go.id/journal/view/1561 2? page $=5$

17. Putri F, Prabamurti P, Mustofa S. FaktorFaktor Yang Mempengaruhi Praktik Phbs Pencegahan Penyakit Tb Paru Pada Santri Di Pondok Pesantren Nurul Hasan Kabupaten Magelang. J Kesehat Masy Univ Diponegoro. 2017;5(3):527-39.

18. Suryani L, Payung S, Pekanbaru N. FaktorFaktor Yang Mempengaruhi Perilaku Hidup Bersih Dan Sehat (Phbs) Siswa/I Sekolah Dasar Negeri 37 Kecamatan Tampan Kota Pekanbaru. J Keperawatan Abdurrab [Internet]. 2018;1(2):17-28. Available from: http://jurnal.univrab.ac.id/index.php/keperawat an/article/view/255

19. Murniani. Hubungan Pengetahuan, Sikap, Tindakan, Pendidikan, Ketersediaan Sarana dan Prasarana dan Sumber Informasi dengan perilaku Hidup Bersih dan Sehat (PHBS) pada Rumah Tangga di Wilayah Kerja Puskesmas Melintang Kota PangkalPinang Tahun 2018. J Smart Ankes [Internet]. 2018;2:32-8. Available from: http://www.jurnalabdinusababel.ac.id/index.ph p/jurnal/article/view/9

20. Kusumaningrum A, Hikayati H, Lengga VM. Faktor - Faktor yang Berpengaruh Terhadap Pemanfaatan Pelayanan Kesehatan Tradisional/Komplementer Pada Keluarga dengan Penyakit Tidak Menular. Semin Nas Keperawatan [Internet]. 2017;1(1):254-63. Available from: http://www.conference.unsri.ac.id/index.php/S 
NK/article/view/780/409

21. Jimung M. Pengaruh guru sebagai role model terhadap motivasi penerapan PHBS siswa di SMP Freater Parepare. J Kesehat Lentera ACITYA. 2019;6(2):40-5.

22. Berliana N. Hubungan Peran Orangtua, Pengaruh Teman Sebaya Dengan Perilaku Hidup Bersih Dan Sehat. J Endur. 2016;1(2):75-80. 